\title{
PENGEMBANGAN POTENSI TEMAJUK SEBAGAI DESTINASI PARIWISATA DI KABUPATEN SAMBAS
}

\author{
Rossi Evita ${ }^{1}$, Tita Rosalina ${ }^{2}$ \\ ${ }^{1}$ Program Studi Manajemen Bisnis Pariwisata, Politeknik Negeri Sambas \\ rossi1604@yahoo.com \\ ${ }^{2}$ Program Studi Manajemen Bisnis Pariwisata, Politeknik Negeri Sambas \\ syafiq605@yahoo.com
}

\begin{abstract}
This study aims to identify tourism potential of Temajuk village that can be developed as a tourism destination in Sambas. The method used was a qualitative descriptive study. Data analysis was qualitative descriptive and SWOT. The results were the tourism potential in Temajuk are Camar Bulan Pier, the Traditional Market, Jellyfish Party, Camar Bulan Beach, Bridge Mangrouve, Grandmother Stone Coast, and the Gulf Atong, Tanjung Dato', Indonesia-Malaysia border gate. In the development of tourism potential Temajuk, the strategies used are to maximize the promotion, development and management of tourist Attractions, increasing human resources, and strategies to improve the safety and supervision of tourism activities.
\end{abstract}

Key word:

development, potential, Temajuk, tourism destination

\begin{abstract}
Abstrak
Penelitian ini bertujuan untuk mengidentifikasi potensi wisata Desa Temajuk yang dapat dikembangkan sebagai destinasi pariwisata kabupaten Sambas. Metode yang digunakan adalah penelitian deskriptif kualitatif. Analisis data yang digunakan yaitu analisis deskriptif kualitatif dan analisis SWOT. Hasil yang diperoleh yaitu potensiwisata yang ada di Temajuk di antaranya yaitu Dermaga Camar Bulan, Pasar Rakyat, Pesta Ubur-ubur, Pantai Camar Bulan, Jembatan Mangrouve, Pantai Batu Nenek, dan Teluk Atong, Tanjung Dato', Gang Durian 8 Batang, Gerbang Perbatasan Indonesia-Malaysia. Dalam pengembangan potensi Temajuk, maka strategi yang digunakan adalah strategi maksimalisasi promosi, strategi pengembangan dan pengelolaan atraksi wisata, strategi peningkatan sumber daya manusia, dan strategi peningkatan keamanan serta pengawasan terhadap aktivitas wisata.
\end{abstract}

Kata kunci:

Destinasi Pariwisata, Pengembangan, Potensi, Temajuk. 


\section{PENDAHULUAN}

Kabupaten Sambas memiliki banyak potensi wisata yang cukup eksotis mulai dari obyek wisata alam maupun budayanya, hal ini disebabkan oleh kondisi geografis alam Kabupaten Sambas yang mendukung serta kearifan budaya lokal yang masih terjaga. Gunung, pantai, danau hingga atraksi budaya menjadi daya tarik tersendiri bagi wisatawan (DISPORABUDPAR, 2014).

Salah satu potensi wisata yang eksotis patut untuk dikembangkan sebagai usaha pariwisata di Kabupaten Sambas adalah Desa Temajuk yang terdapat di Kecamatan Paloh. Desa Temajuk merupakan salah satu desa yang banyak memiliki potensi wisata, khususnya wisata alam. Hamparan pantai yang terdapat di desa ini memiliki keindahan tersendiri, karena desa ini juga dijuluki sebagai kawasan wisata alam. Potensi wisata yang terdapat di Temajuk merupakan tempat wisata yang masih alami belum dikembangkan sebagai usaha dibidang pariwisata, hal lain yang menjadi permasalahan didalam pengembangan ini adalah pengelolaan sarana dan prasarana sebagai fasilitas pendukung serta kondisi infrastruktur yang belum memadai serta pengelolaan tempat wisata yang belum optimal.

Desa Temajuk merupakan daerah tujuan wisata (destinasi pariwisata) yang diminati oleh wisatawan lokal maupun domestik, hal ini ditandai dengan setiap tahunnya yaitu berkisar pada bulan Mei-Juni di selenggarakan Pesta Wisata Temajuk. Tujuan dari diselenggarakannya pesta wisata temajuk ini salah satunya adalah untuk menarik perhatian turis/wisatawan dalam rangka mengenalkan atau mempromosikan tempat wisata yang indah dan masih alami dan belum banyak tersentuh oleh pengelola pariwisata/investor.

Mengingat Desa Temajuk adalah salah satu desa yang berbatasan langsung dengan Negara tetangga (Malaysia) yaitu berbatasan dengan Telok Melano, tidak menutup kemungkinan tempat ini akan dikunjungi banyak wisatawan. Selain menikmati keindahan alam serta keunikan budaya lokal, wisatawan juga bisa menginjakkan kaki ke Negara tetangga Malaysia yaitu Teluk Melano tanpa dokumen resmi (Paspor) layaknya wisatawan pergi ke Negara lain, oleh karena itu, fenomena alam desa Temajuk merupakan salah satu peluang pengembangan pariwisata.

Berdasarkan latar belakang yang telah dipaparkan di atas, dengan ini dirumuskan masalah yaitu: "Potensi apa saja yang dapat dikembangkan diDesa Temajuk sebagai destinasi pariwisata Kabupaten Sambas". Masalah yang akan diteliti dirumuskan dengan pendekatan analisis deskriptif dengan menggunakan teori dan konsep sistem pariwisata. Penelitian ini berkaitan dengan strategi pengembangan potensi wisata sebagai destinasi pariwisata di kabupaten Sambas. Adapun tujuan penelitian adalah untuk mengidentifikasi potensi-potensi wisata apa saja yang dapat dikembangkan di Desa Temajuk Kabupaten Sambas sebagai Destinasi Pariwisata.

\section{METODE PENELITIAN}

Tahapan-tahapan dalam penelitian ini di antaranya yaitu: membaca literatur-literatur terkait, mencari informasi bagaimana kondisi/ akses masuk ke lokasi penelitian, masuk ke lokasi penelitian dan menjalin hubungan sosial masyarakat setempat, mengamati, menyimak, menelaah dan mengumpulkan data-data penting, mulai menganalisa data, membangun kerangka pemikiran, melakukan wawancara dengan masyarakat setempat, dan mencari informan kunci sesuai dengan kriteria yang sudah ditetapkan, analisis data yang sudah diperoleh dan menyusun laporan.

Jenis data yang digunakan dalam penelitian ini adalah data kualitatif dan kuantitatif. Data kualitatif adalah data yang dinyatakan dalam bentuk kalimat atau uraian. Sementara itu, data kuantitatif adalah jenis data yang dinyatakan dalam bentuk angka (Nawawi, 2007: 103). 
Penelitian ini menggunakan kedua jenis data tersebut, yaitu data kualitatif dan data kuantitatif. Data kualitatif yang dimaksud mencakup informasi-informasi,uraian-uraian yang relevan maupun data yang lain yang didapat dari informan langsung maupun sumber lain, guna kelengkapan data yang diperlukan, sedangkan data kuantitatifnya yang berupa angka-angka seperti jumlah penduduk, jumlah potensi wisata yang dimiliki dan lain-lain.

Sumber data yang digunakan dalam penelitian ini dikelompokkan menjadi dua, yaitu sumber data primer dan data sekunder. Dimana sumber data primer radalah sumber data yang diperoleh langsung dari informan atau data yang telah dikumpul dari responden yang sudah ditetapkan. Sumber data sekunder yaitu sumber data yang diperoleh secara langsung atau data yang diperoleh dari dokumen arsip resmi dari desa atau instansi yang terkait seperti peta geografis dan demografis lokasi yang akan diteliti maupun dokumen seperti buku-buku koleksi perpustakaan umum maupun pribadi, jurnal, brosur, webside serta data yang diperoleh dari pemerindah Kabupaten Sambas.

Metode yang digunakan dalam penentuan informan adalah metode purposive, yaitu cara penentuan yang berdasarkan atas tujuan tertentu dan atas pertimbangan peneliti. Menurut Mardailis, (2008), informasi yang ditetapkan sesuai dengan penelitiannya dan memiliki kriteria, yaitu:

(1) mereka yang mengetahui informasi sehubungan dengan masalah yang diteliti;

(2) merekayang diterimaolehberbagaikelompok yang terkait dengan pengembangan;
(3) mereka yang memiliki pengetahuan tentang pariwisata.

Adapun analisis data yang digunakan dalam penelitian ini yaitu analisis deskriptif kualitatif. Analisis data deskriptif kualitatif ini sifatnya tidak terlalu mengutamakan makna, sebaliknya, penekanannya pada deksriptif menyebabkan format deskiptif kualitatif lebih banyak menganalisis permukaan data, hanya memperhatikan proses-proses kejadian suatu fenomena, bukan kedalaman data atau makna data. Analisis SWOT digunakan dalam pengembangan potensi wisata Desa Temajuk, yaitu memerlukan langkah-langkah atau strategi dalam mengembangkan potensi Desa Temajuk sebagai destinasi pariwisata. Informan kunci dalam penelitian ini berjumlah 20 orang.

\section{HASIL DAN PEMBAHASAN}

Pengembangan potensi pariwisata Desa Temajuk dapat dilihat dari 3 aspek yaitu attraction (daya tarik), amenities (fasilitas), dan accessibility ( aksesibilitas), yaitu:

Attraction (daya tarik)

Potensi wisata yang dapat dikembangkan menjadi destinasi pariwisata terdapat 11 tempat wisata yang terletak pada tiga dusun di desa Temajuk diantaranya: Tugu Garuda, Dermaga Camar Bulan, Pasar Rakyat, Pesta Ubur-ubur, Pantai Camar Bulan, Jembatan Mangrouve, Pantai Batu Nenek, dan Teluk Atong, Tanjung Dato', Gang Durian 8 Batang, Gerbang Perbatasan Indonesia-Malaysia. Potensi wisata Temajuk dapat dilihat pada tabel 3.1. 
Tabel 3.1 Potensi Wisata di Desa Temajuk

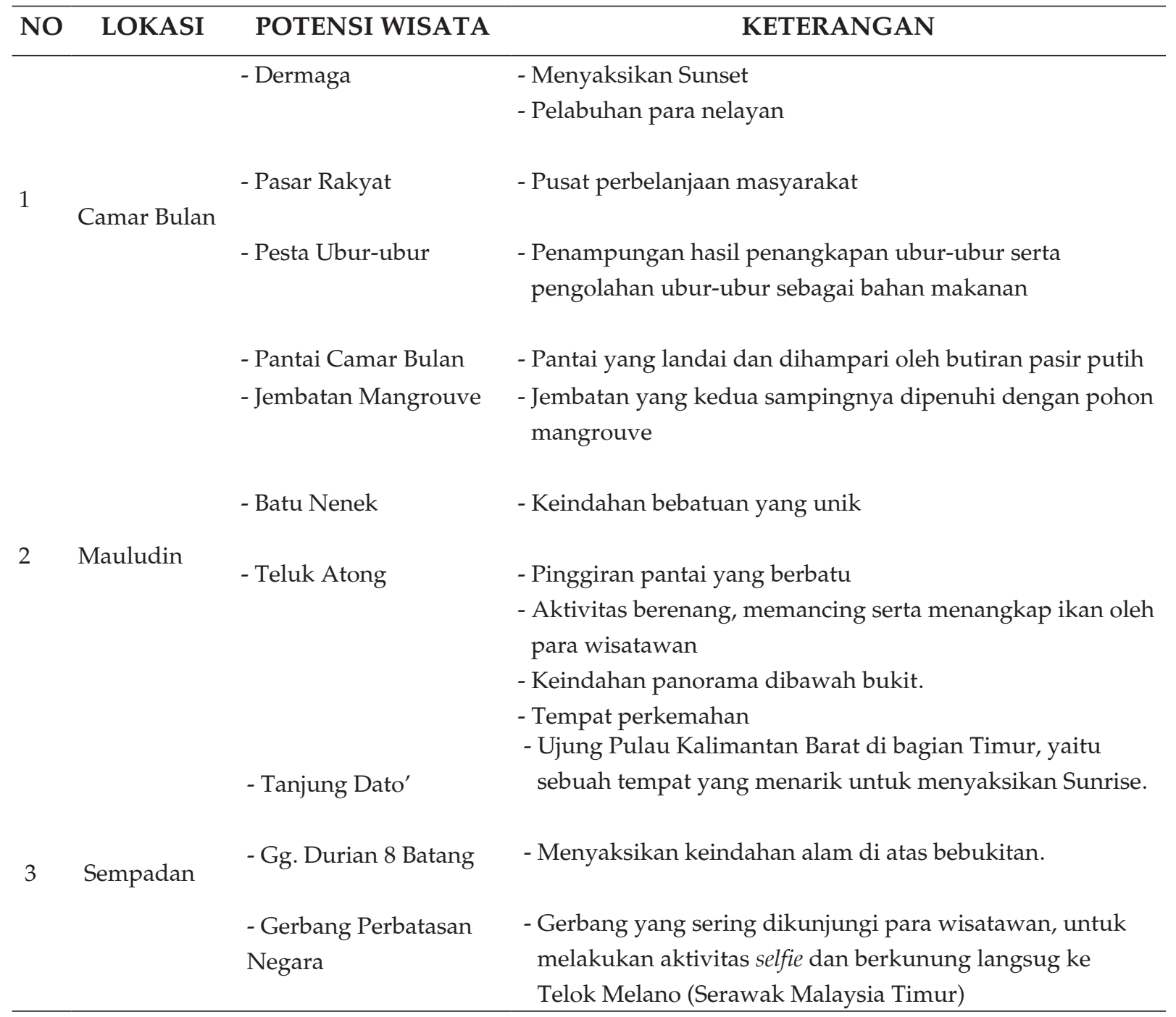

Sumber: Data Primer, 2016

\section{Amenities (fasilitas)}

Para pengunjung /wisatawan dapat menikmati fasilitas-fasilitas yang disediakan oleh warga setempat berupa penginapan seperti home stay dan vila / resort yang sederhana, hanya saja penginapan yang berupa hotel standar belum tersedia di daerah ini. Adapun penginapan yang tersedia di Desa Temajuk yaitu : Penginapan Atong Bahari, JLO, Tiara, Setia Menanti, Monggok Long Biin, Jeni Spasy, Kelapa Dua, Restu, Camar Bulan. Selain beberapa penginapan tersedia, para pengunjung juga dapat menikmati home stay yang di sediakan warga setempat.
Oleh karena itu para pengunjung tidak merasa kuatir akan daya tampung penginapan yang tersedia, karena sebagian besar rumah warga desa ini dijadikan sebagai home stay.

Selain penginapan, untuk fasilitas rumah makan, para pengunjung dapat menikmati makanan khas warga setempat atau sesuai menu keinginan pengunjung yang disediakan di tempat-tempat penginapan yaitu tempat mereka menginap, maupun warung makanan/rumah makan yang tersedia di pasar yang berlokasi di Camar Bulan. Disamping itu, fasilitas umum juga tersedia di tempat ini seperti, 
mesjid dan mushola dan lain-lain.Hanya saja yang menjadi kendala di desa Temajuk adalah jaringan telekomunikasi dan listrik yang kurang memadai.

\section{Accessibility (aksesibiltas)}

Begitu banyak potensi yang dapat dikembangkan sebagai destinasi pariwisata di desa ini, untuk menuju lokasi wisata (Desa Temajuk) jarak tempuh yang harus dilalui kurang lebih $100 \mathrm{~km}$ dari ibukota kabupaten, wisatawan dapat menggunakan akses jalur darat dan air. Jalur darat dapat dilalui atau ditempuh dengan menggunakan kendaraan roda empat dan roda dua dengan 2 kali penyebrangan, sedangkan untuk jalur air, dapat menggunakan motor air maupun kapal yang digunakan oleh warga untuk membawa barang-barang keperluan rumah tangga dan lain-lain.

Potensi wisata yang telah dituliskan di atas, dapat dikembangkan sebagai destinasi pariwisata khususnya di Desa Temajuk Kabupaten Sambas. Oleh karena itu, diperlukan strategi-strategi yang tepat untuk mewujudkan pengembangan potensi wisata tersebut. Sebelum merumuskan strategi-strategi yang tepat, terlebih dahulu mengetahui kondisi internal dan eksternal strategi pengembangan potensi wisata tersebut. Adapun kondisi internal dan ekstrnal potensi wisata Desa Temajuk yaitu:

\section{Kondisi Internal Pengembangan Potensi Wisata Desa Temajuk}

\section{Kekuatan (Strengths)}

Kekuatan adalah segala sesuatu yang dapat dikembangkan sebagai andalan potensi desa Temajuk sebagai destinasi pariwisata, (Potensi/ daya tarik wisata yang dimiliki). Kekuatan desa Temajuk ini memiliki keunggulan atau kelebihan dibandingkan dengan tempat wisata yang lain di daerah Kabupaten Sambas. Adapun keunggulan atau kelebihannya yaitu:

\section{Keindahan Kawasan Alam Yang Eksotis}

Keindahan alam yang dimiliki desa Temajuk merupakan suatu anugerah dari Sang Pencipta yang patut untuk kita pelihara dan dilestarikan. Kawasan alam desa Temajuk merupakan kawasan wisata yang sangat beragam dan berbeda dengan keindahan kawasan wisata yang ada di Kabupaten Sambas, selain memiliki kawasan pantai dengan hamparan pasir putih serta tepian pantai yang berbatu, kawasan desa ini juga berbukit-bukit. Di ketinggian bukit yang ada, terlihat sekali keindahan yang sejuk dan asri dengan panorama yang menghijau dan dihuni oleh berbagai jenis satwa seperti spesies kera, burung, dll. Eksotisme kawasan desa Temajuk ini juga bisa dirasakan oleh pengunjung yang datang kesana ketika melihat langsung sun rise dan sun set, begitu juga dengan keindahan di dalam laut, bahwa banyak terumbu karang yang sangat indah. Hanya saja masyarakat setempat masih banyak yang belum mengetahui keberadaan terumbu karang didaerahnya.

\section{Pesta Wisata Temajuk}

Pesta wisata temajuk dapat di nikmati setiap tahunnya yaitu bermula sekitar bulan meijuli. Adapun kegiatan pesta temajuk tersebut diselenggarakan dengan berbagai hiburan rakyat seperti pesta pantai. Pesta tersebut diisi dengan berbagai kegiatan-kegiatan yang sengaja diciptakan untuk menarik perhatian banyak pengunjung atau wisatawan.

\section{Pesta Ubur-ubur}

Pesta ubur-ubur disebut juga dengan panen ubur-ubur (penangkapan ubur-ubur dengan jumlah yang melimpah oleh nelayan), dengan adanya ubur-ubur dengan jumlah yang banyak ini dirasakan oleh masyarakat setempat sebagai suatu anugerah rezeki Sang Pencipta. Kegiatan pesta ubur-ubur ini terjadi satu tahun sekali, yaitu bermula dari bulan Februari-bulan Mei. Oleh karena itu, masyarakat setempat sangat bersyukur ketika panen ubur-ubur berlangsung.

\section{\begin{tabular}{l|l} 
JNP & 48
\end{tabular}}


Selain menambah pendapatan sehari-hari bagi mereka, kegiatan tersebut dapat menciptakan lapangan pekerjaan baru bagi mereka, meskipun mereka bukan seorang nelayan. Tidak hanya laki-laki yang bisa menikmati dari hasil panen ubur-ubur ini, melainkan wanita juga bisa menikmati hasil dari panen ubur-ubur tersebut. Umumnya laki-laki bertugas sebagai penangkap ubur-ubur dan menjualnya langsung pada tempat pengolahan ubur-ubur yang berlokasi di kawasan camar bulan, sementara wanita berkerja mengolah ubur-ubur tersebut dari pembuangan lendir, perendaman, pengawetan dll. Hasil dari olahan ubur-ubur ini di jual dalam negeri dan di eskspor ke luar negeri seperti negara Malaysia, Cina, Jepang dll.

\section{Berbatasan Langsung Dengan Negara Malaysia (Teluk Melano)}

Untuk menuju daerah perbatasan negara ini, terlebih dahulu pengunjung wajib melaporkan diri pada penjaga pos keamanan dengan mengisi data pribadi masing-masing dan tujuan mereka berkunjung. Setelah di berikan ijin keluar, pengunjung dapat menikmati keindahan alam yang menghijau sepanjang perjalanan mereka, setelah itu para pengunjung dapat mengabadikan moment kedatangan mereka di sekitar gerbang perbatasan Indonesia-Malaysia. Setelah itu, pengunjung juga wajib melaporkan diri pada penjaga pos keamanan untuk ijin masuk wilayah Malaysia dengan melihatkan identitas diri masing-masing. Apabila para pengunjung telah mendapatkan izin masuk ke wilayah Malaysia, para pengunjung dapat merasakan dan menikmati perbedaan budaya (arsitektur bangunan rumah yang khas) serta tempat-tempat wisata yang ada disana tanpa adanya retribusi tiket masuk lokasi wisata.

\section{Kelemahan (Weakness)}

Kelemahan merupakan suatu keadaan pada objek yang kurang menguntungkan dalam mengembangkan potensi Desa Wisata sebagai destinasi pariwisata, yaitu apa saja yang perlu diatasi sehingga layak untuk dikembangkan dan tidak memberikan dampak negatif yang mempengaruhinya. Terdapat beberapa kelemahan terhadap potensi-potensi wisata di Desa Temajuk, diantaranya yaitu:

\section{Minimnya Sarana dan Prasarana wisata}

Sarana dan prasarana wisata merupakan salah satu unsur penting dalam aktivitas wisata. Namun, ketika berkunjung ke desa Temajuk, sarana dan prasarana wisata yang ada seperti, minimnya instalasi tenaga listrik dan sistem telekomunikasi. Instalasi tenaga listrik dan jaringan telekomunikasi sangatlah penting bagi kebutuhan wisatawan, instalasi tenaga listrik/ arus listrik di desa ini sangat terbatas, yaitu hanya bisa dijangkau daerah-daerah terdekat dengan Camar Bulan saja. Tidak hanya itu, keterbatasan penggunaan listrik juga sangat dirasakan penduduk/masyarakat, karena arus listrik hanya bisa digunakan pada malam hari saja, berhubung kapasitas arus listrik sangat terbatas. Dengan keterbatasan arus listrik tersebut, begitu juga sarana penyediaan makan dan minum sangat minim, hanya ada pada tempat-tempat tertentu saja. Dengan kondisi yang sangat jauh dari pusat kota dan arus listrik tidak memadai, penyediaan makan dan minum hanya bisa kita dapatkan di tempat-tempat penginapan saja.

\section{Pengelolaan Infrastruktur belum memadai}

Kondisi jalan utuk menuju desa Temajuk masih belum memadai, karena sebagian jalan masih ada yang belum beraspal. Jika musim panas, kondisi jalan berdebu dan jika musim penghujan kondisi jalan menjadi licin dan bahkan kondisi jalan menjadi becek. Alternatif lain dari penggunaan darat, pengunjung juga bisa menggunakan jalan air, namun harus melihat kondisi cuaca yang memungkinkan terlebih dahulu. 


\section{Jarak Tempuh Dari Pusat Kota Kabupaten}

Jarak tempuh dari pusat kota kabupaten dengan desa ini sangatlah jauh, dengan jara $\pm 100 \mathrm{~km}$, dengan jarak tempuh yang sangat jauh, dan kondisi jalan yang belum memadai dikarenakan desa ini merupakan desa yang paling utara wilayah Kabupaten Sambas.

\section{Minimnya Jaringan Telekomunikasi}

Sarana telekomunikasi di desa ini sangatlah minim (tidak lancer). Sulitnya untuk berkomunikasi dirasakan apabila kita sudah tiba di wilayah desa Temajuk, jaringan telekomunikasi bisa didapat hanya pada tempattempat tertentu saja, dan bahkan terkadang tidak ada sama sekali jaringan telekomunikasi. Penyebab utamanya adalah minimnya arus tenaga listrik.

\section{Promosi Belum Maksimal}

Promosi ini berkaitan erat dengan pemasaran, karena kegiatan promosi ini merupakan bentuk komunikasi dengan khalayak ramai atau pasar sasaran, melalui informasi dari mulut ke mulut, melalui iklan, website, melalui penjualan perorangan, maupu media promosi lainnya sehingga dapat mengenalkan desa ini pada wisatawan lokal, domestik, nusantara maupun wisatawan dunia. Namun, belum maksimalnya promosi yang dilakukan di tandai dengan masih banyaknya wisatawan domestik belum mengetahui keberadaan desa Temajuk sebagai tempat wisata alam yang indah berbeda dengn tempat lainnya khususnya di daerah Kabupaten Sambas.

\section{Kondisi Eksternal Pengembangan Potensi Wisata Desa Temajuk}

\section{Peluang (Opporthunities)}

Peluang merupakan faktor-faktor dari luar yang dapat mendorong pengembangan potensi wisata Desa Temajuk atau segala sesuatu yang memberikan kesempatan untuk meningkatkan pengembangan potensi wisata desa Temajuk sebagai destinasi pariwisata. Peluang tersebut diantaranya:

\section{Ragam Atraksi wisata Alam}

Ragam atraksi wisata alam ini bisa kita nikmati seperti yang ada di daratan maupun di laut. Atraksi didarat seperti halnya mendaki bukit, bumi perkemahan, melihat satwa penyu, kera,burung, menikmati keindahan alam sepanjang perjalanan, keindahan hutan mangrouve, sementara atraksi di laut yang dapat dilakukan adalah memancing, berenang, menyelam (melihat terumbu karang), serta merentasi pinggiran pantai menggunakan sampan sampai ke kawasan tanjung datok.

\section{Event Temajuk}

Event Temajuk pada umumnya juga dilaksanakan di sekitar kawasan desa temajuk seperti perlombaan motor cross, pertunjukan budaya setempat maupun pesta yang sifatnya diadakan secara musiman, bedanya dengan pesta wisata Temajuk adalah waktu pertunjukannya. Event Temajuk diselenggarakan sifatnya musiman sementara pesta wisata temajuk diselenggarakan secara rutin setiap tahunnya.

\section{Kawasan Perkebunan dan Perikanan}

Desa Temajuk juga memiliki kekayaan alam seperti area perkebuan dan perikanan. Khususnya perikanan, di kawasan temajuk ini juga dikenal dengan masih banyaknya berbagai jenis ikan. Begitu juga dengan perkebunan, di kawasan ini terdapat perkebunan karet, lada dll.

\section{Habitat Satwa Langka}

Terdapatnya satwa langka di desa ini juga merupakan ikon ketertarikan khusus bagi wisatawan, adapun satwa langka tersebut adalah spesies penyu. Bagi wisatawan yang beruntung bisa menyaksikan aktivitas penye di malam hari.

\section{JNP ${ }_{50}$}


Karena di beberapa tempat khususnya kawasan desa temajauk satwa langka ini melakukan aktivitas bertelur didaratan.

\section{Ancaman (Threats)}

\section{Ancaman Kerusakan Lingkungan}

Kerusakan lingkungan dapat berdampak bagi masyarakat setempat maupun sekitar, dan bahkan pada hewan penghuni hutan. Penyebab kerusakan lingkungan ini juga bukan hanya dari pengunjungsaja,melainkanmasyarakatsetempat juga terlibat didalamnya. Kelestarian lingkungan sekitar sangat penting untuk kelangsungan hidup berikutnya. Jika kurangnya pengendalian pengunjung maupun masyarakat setempat terhadap kesadaran terhadap lingkungan seperti membuang sampah sembarangan dan menebang serta membakar hutan sembarangan dapat menyebabkan kerusakan lingkungan lingkungan. Bukan hanya itu, kapasitas pengunjung juga perlu diperhatikan, karna jika daya tampung pengunjung yang melampaui batas juga bisa menyebabkan ketidak sbabilan terhadap lingkungan sekitar seperti penyediaan saranan akomodasi dan penjaga keamaan yang tidak maksimal.

\section{Akulturasi Budaya}

Akulturasi budaya adalah pergeseran budaya lokal terhadap budaya baru yang datangnya dari budaya luar. Jika masyarakat setempat tidak membentengi diri dan tidak melestarikan budaya lokal dengan baik, maka akan mudahnya budaya asing untuk di adopsi oleh masyarakat setempat. Seiring dengan perkembangan zaman dan trend globalisasi yang masuk kedaerah kita juga menjadi pandangan penting bagi masyarakat setempat agar tidak terpengaruh dengan budaya luar/asing.

\section{Suplay Kebutuhan Pokok}

Suplay kebutuhan pokok masyarakat desa Temajuk ini sangat ketergantungan pada negara tetangga khususnya daerah Telok
Melano. Mereka lebih memilih berbelanja ke negara tetangga ketimbang berbelanja di daerah kecamatan Paloh, berhubung jarak tempuh yang dilalui dan perkisaran harga kebutuhan pokok lebih murah dari masyarakat berbelanja di ibu kota kecamatan Paloh. Selain jarak tempuh dari ibu kota kecamatan ke desa Temajuk, perbedaan harga kebutuhan pokok juga merupakan prioritas mereka untuk berbelanja. Harga yang murah didapat dikarenakan tidak adanya bea cukai / pajak terhadap barang yang mereka beli di wilaya Teluk Melano, hanya dengan pertukaran nilai rupiah dan ringgit.

\section{Minimnya Penjagaan Keamanan di Tempat Wisata}

Sangat diraksakan minimnya petugas keamanan ketika para pengunjung atau wisatawan berada di lokasi tempat wisata di desa Temajuk. Selain itu, setiap pengunjung merasa kesulitan untuk mendapatkan pelayanan tentang informasi terkait dengan aktivitas wisata. Pengunjung harus berhati-hati untuk menjaga apa yang mereka miliki seperti motor. Karena juru parkir pun sangat jarang ditemukan di area wisata yang kita tuju.

Uraian di atas menjelaskan bahwa diperoleh beberapa faktor internal dan eksternal dalam pengembangan potensi wisata Desa Temajuk. Selanjutnya akan dirumuskan strategistrategi yang digunakan dalam pengembangan potensi wisata tersebut. Perumusan strategi pengembangan tersebut dapat di lihat pada tabel 3.2. 
Tabel 3.2 Matrik Strategi Pengembangan Potensi Desa Temajuk

\begin{tabular}{|c|c|c|}
\hline & KEKUATAN (S) & KELEMAHAN (W) \\
\hline$x$ & $\begin{array}{l}\text { 1. Keindahan Kawasan Alam Yang } \\
\text { Eksotis } \\
\text { 2. Pesta Wisata Temajuk } \\
\text { 3. Pesta Ubur-ubur } \\
\text { 4. Berbatasan Langsung Dengan } \\
\text { Negara Malaysia (Teluk Melano) }\end{array}$ & $\begin{array}{l}\text { 1. Minimnya Sarana dan Prasarana wisata } \\
\text { 2. Pengelolaan Infrastruktur belum memadai } \\
\text { 3. Jarak Tempuh Dari Pusat Kota Kabupaten } \\
\text { 4. Minimnya Jaringan Telekomunikasi } \\
\text { 5. Promosi Belum Maksimal }\end{array}$ \\
\hline PELUANG $(\mathrm{O})$ & STRATEGIS-O & STRATEGI W-O \\
\hline $\begin{array}{l}\text { 1. Ragam Atraksi wisata } \\
\text { Alam } \\
\text { 2. Event Temajuk } \\
\text { 3. Kawasan Perkebunan dan } \\
\text { Perikanan } \\
\text { 4. Habitat Satwa Langka }\end{array}$ & Strategi Maksimalisasi Promosi & $\begin{array}{l}\text { Strategi Pengembangan dan Pengelolaan Atraksi } \\
\text { Wisata. }\end{array}$ \\
\hline ANCAMAN (T) & STRATEGI S-T & STRATEGI W-T \\
\hline $\begin{array}{l}\text { 1. Ancaman Kerusakan } \\
\text { Lingkungan } \\
\text { 2. Akulturasi Budaya } \\
\text { 3. Suplay Kebutuhan Pokok } \\
\text { 4. Minimnya Penjagaan } \\
\text { Keamanan di Tempat } \\
\text { Wisata }\end{array}$ & $\begin{array}{l}\text { Stragi Peningkatan Sumber Daya } \\
\text { Manusia }\end{array}$ & $\begin{array}{l}\text { Strategi Peningkatan Keamanan serta Pengawasan } \\
\text { Terhadap Pengelola Wisata }\end{array}$ \\
\hline
\end{tabular}

Sumber : Data Primer, 2016

Berdasarkan rumusan kondisi internal dan eksternal pengembangan potensi wisata desa Temajuk, ada beberapa strategi pengembangan Potensi yang dapat dikembangkan di Desa Temajuk sebagai destinasi pariwisata yaitu:

\section{1) Strategi Maksimalisasi Promosi}

Strategi maksimalisasi promosi dilakukan dengan berbagai cara, seperti pemasangan iklan baik media cetak maupun elektronik, penyebaran brosur di tempat-tempat umum seperti airport, mengadakan seminar, event serta pelayanan informasi pariwisata. Pelaksanaan promosi ini bukan hanya dilakukan oleh dinas pariwisata setempat, melainkan dilakukan oleh pengelola tempat wisata, kelompok sadar wisata dan bahkan dapat dilakukan oleh masyarakat setempat yang peduli akan keindahan daerah yang dimiliki untuk mengeksplor ke dunia luar.

\section{2) Strategi Pengembangan dan Pengelolaan Atraksi Wisata}

Desa temajuk memiliki keindahan wisata alam/bahari, hanya saja pengelolaan dari desa ini sebagai tempat wisata masih belum memadai. Dengan keindahan alam yang masih alami, pesona alam yang terkesan natural membuat para wisatawan terpesona akan keindahannya. Penyedian atau penyajian fasilitas wisata juga masih sangat sederhana seperti belum adanya hotel standar, melainkan homestay yang disediakan oleh warga setempat maupun pengelola tempat wisata. Penyediaan tempattempat makan serta penyajian atraksi wisata yang belum bervariatif. Hal ini dikarenakan kurangnya kerjasama pengelola hotel setempat dengan pihak investor.

Perlunya pengembangan serta pengelolaan atraksi wisata oleh pihak terkait tidak terlepas 
dari adanya kerjasama dengan berbagai pihak. Dengan adanya dukungan dari berbagai pihak tersebut, maka tempat wisata yang akan dikelola akan mengalami perubahan dari sebelumnya. Adapun strategi pengembangan pengelolaan atraksi wisata dapat dikembangkan seperti menciptakan atraksi yang sebelumnya lebih menarik dan menambah atraksi wisata yang belumnya belum pernah ada, seperti menambah fasilitas-fasilitas wisata air (snorkeling, glass bottom, banana boat dan lain-lain), menciptakan arena permainan anak maupun orang dewasa di kawasan tempat wisata, adanya wisata pertualangan seperti mendaki bukit, atraksi sepeda gunung, serta merentasi hutan yang masih alami. Banyak hal yang dapat dilakukan dalam upaya pengembangan serta pengelolaan atraksi wisata. Selain menciptakan atraksi wisata, di desa ini juga sangat minim akan souvenir untuk para pengunjung, hanya beberapa souvenir saja yang dapat mereka bawa pulang sebagai oleh-oleh berkunjung ke daerah tersebut.

\section{3) Strategi Peningkatan Sumber Daya Manusia}

Adapun strategi ini dapat dilakukan dengan cara mengikuti pendidikan dan pelatihan. Adanya pendidikan dan pelatihan sumberdaya manusia ini, hal yang paling utama yaitu mempelajari tentang standar pelayanan, pengelolaan tempat wisata yang baik, peningkatan skill atau keterampilan berbahasa asing serta pengelolaan manajemen tempat wisata.

\section{4) Strategi Peningkatan Keamanan Serta Pengawasan Terhadap Aktivitas Wisata}

Keamanan serta kenyamanan pengunjung/ turis menjadi prioritas utama dalam usaha pariwisata, pelayanan yang prima dapat memberikan kesan baik kepada para pengunjung. Begitu juga dengan segala aktivitas wisata yang dikelola juga memrerlukan pengawasan yang intensif. Pengawasan dapat dilakukan oleh beberapa orang yang diberi wewenang dan tanggung jawab sesuai dengan bidangnya.

Tujuan dari adanya peningkatan keamanan ini adalah agar proses atraksi wisata berlangsung jauh dari berbagai gangguan yang tidak diingini seperti adanya keributan, pencurian, maupun perbuatan-perbuatan yang membuat para wisatawan ketakutan atau merasa tidak aman. Langkah yang tepat untuk meningkatkan keamanan ini yaitu dengan menambah beberapa personil keamanan (security). Faktanya dibeberapa tempat wisata desa temajuk, keberadaan security sangat jarang ditemukan, apalagi desa ini berbatasan langsung dengan negara lain, maka tidak menutup kemungkinan turis asing juga akan berkunjung ke desa ini, apalagi untuk masuk wilayah ini, tidak memerlukan persyaratan yang menyulitkan bagi turis asing.

Selain menambah pos-pos keamanan/ personil penjaga keamnaan, yang letaknya di setiap tempat wisata, perlu juga adanya pengawasan dari pihak pengelola tempat wisata yang berkerjasama dengan pihak kepolisian setempat maupun TNI yang bertugas didaerah perbatasan. Tujuannya adalah dengan adanya kerjasama dari berbagai pihak pengawasan akan mudah untuk dilakukan tanpa adanya ketidaknyamanan dari pihak yang terkait.

\section{KESIMPULAN}

Berdasarkan hasil penelitian yang sudah dicapai,dapat ditarik kesimpulan bahwa hasil identifikasi potensi-potensi wisata yang terdapat di desa Temajuk sebagai destinasi pariwisata Kabupaten Sambas yaitu yang terdapat pada tiga dusun diantaranya: a) Dusun Camar Bulan, terdapat beberapa potensi wisata yaitu, Dermaga Camar Bulan, Pasar Rakyat, Pesta Ubur-ubur, Pantai Camar Bulan; b)Dusun Mauludin, dusun ini juga sering dikunjungi wisatawan untuk menyaksikan atau menikmati 
keindahan Jembatan Mangrouve, Pantai Batu Nenek, dan Teluk Atong; c)Dusun Sempadan, dusun ini merupakan berbatasan langsung dengan negara Malaysia yaitu Teluk Melano, di dusun ini terdapat potensi wisata yaitu Tanjung Dato' (dikenal dengan border MALINDO), Gang Durian 8 Batang, Gerbang Perbatasan IndonesiaMalaysia.

Strategi pengembangan potensi wisata Temajuk sebagai destinasi pariwisata yaitu: a. Strategi Maksimalisasi Promosi, b. Strategi Pengembangan dan Pengelolaan Atraksi Wisata, c. Strategi Peningkatan Sumber Daya Manusia, d. Strategi Peningkatan Keamanan serta Pengawasan Terhadap Aktivitas Wisata.

\section{DAFTAR PUSTAKA}

Anonim. 2014. Profil Pariwisata Kabupaten Sambas. Sambas: DISPORABUDPAR

Anonim.2009. Undang Undang Republik Indonesia Nomor 10 Tahun 2009

Kusdianto, Hadinoto. 1996. Perencanaan Pengembangan Destinasi Pariwisata. Jakarta: UI-Pers

Mardalis. 2008. Metode Penelitian (Suatu Pendekatan Proposal). Jakarta: Bumi Aksara

Mulyana, Bedi. 2012. Jurnal ilmiah pariwisata (Destinasi Kreatif dan Partisipasi masyarakat lokal). Denpasar .Ikatan alumni kajian pariwisata universitas udayana.

Nawawi, Hadiri. 2007. Metodelogi Penelitian. Jakarta: Rajawali Pers

Pitana, I Gde dan Diarta, I Ketut Surya. 2009. Pengantar Ilmu Pariwisata. Yogyakarta: Andi

Rosalina, Tita. 2010. Strategi Pengembangan Kawasan Danau Sebedang sebagai Daya Tarik Wisata di Kabupaten Sambas Provinsi Kalimantan Barat (Tesis Program Magister Pariwisata). Denpasar. Universitas Udayana.

Sabahan. 2011. Catatan Anak Rantau. Jakarta: Sedaun

Sabahan. 2011. Pesona Ekowisata Temajuk. Jakarta: Sedaun

Sugiono. 2010. Metodelogi Penelitian Kuantitatif Kualitatif Dan RED. Bandung: Alfabet 